\title{
- Restabelecimento do trânsito intestinal em equiiinos Parte I: fisiologia e fisiopatologia
}

\section{- Reestablisment equine intestinal transit Part I: physiology and physiopathology}

\author{
Armen Thomassian-CRMVSPn ${ }^{0} 1113$ \\ Professor Titular \\ Departamento de Cirurgia e Anestesiologia Veterinária \\ Serviço de Cirurgia em Grandes Animais
}

Faculdade de Medicina Veterinária e Zootecnia UNESP - Botucatu Departamento de Cirurgia e Anestesiologia Veterinária Distrito de Rubião Júnior CEP 18618-000 Botutacu - SP Tel. (014) 820-6252

E-mail: thomassian@fmvz.unesp.br

\section{RESUMO}

O trabalho aborda os principais aspectos da fisiologia do trânsito gastroentérico dos eqüinos, assim como apresenta detalhes da fisiopatogenia da obstrução funcional e mecânica do trato digestivo.

Palavras chaves: Eqüinos, Fisiologia, Aparelho digestório, Trânsito intestinal, Ileus, Cólica

\section{Introdução}

Quando se trata de afecções que se localizam no aparelho digestório dos eqüinos, o médico veterinário sempre deve encará-las à luz dos conceitos de Urgência e Emergência, assim considerando-as em qualquer que seja a situação clínica.

Conforme Resolução do Conselho Federal de Medicina (CFM) nº1451 de 10 de março de 1995 são consideradas:

1 - URGÊNCIA: ocorrência imprevista de agravo à saúde com ou sem risco potencial de vida.

2 - EMERGÊNCIA: a constatação médica de condições de agravo à saúde que impliquem em risco iminente de vida ou sofrimento intenso, exigindo, portanto, tratamento médico imediato.

Estes conceitos básicos, quase dogmáticos, para o comportamento do profissional médico, podem também servir ao médico veterinário quando acrescidos da qualificação potencial de perda de função, podendo ser enunciados da seguinte forma:

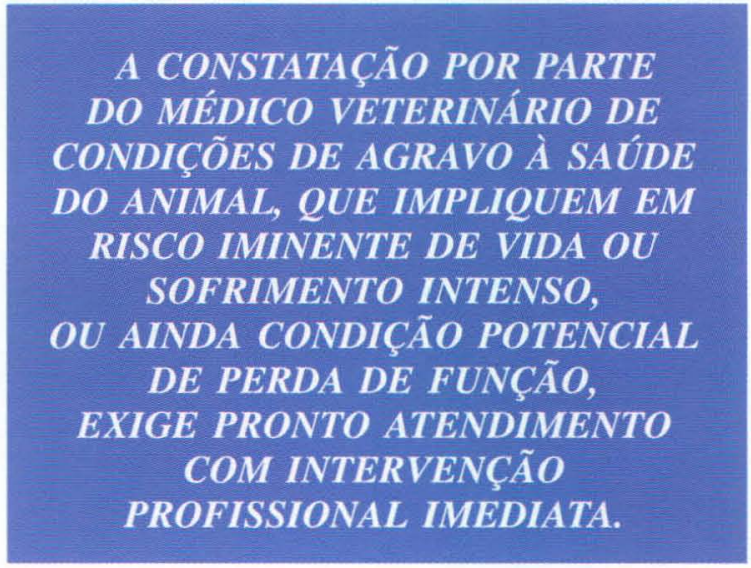

Sob esta ótica, com relação ao aparelho digestório dos eqüinos, qualquer processo que implique em comprometimento da digestão e progressão dos alimentos, ou determine manifestações de dor, deve ser considerado uma situação de EMERGÊNCIA, vez que poderá resultar em patogenias que poderão precipitar a parada do trânsito do digesta, e como possível consequiência precipitar a morte do animal.

A obstrução ou a parada ao trânsito intestinal dos alimentos deve ser considerada sob o ponto de vista clíni- 
THOMASSIAN, ARMEN. Restabelecimento do trânsito intestinal em eqüinos - Parte I: fisiologia e fisiopatologia. Revista de Educação Continuada do CRMV-SP / Continuous Education Journal CRMV-SP. São Paulo, volume 2, fascículo 1, p. 9 - 16, 1999.
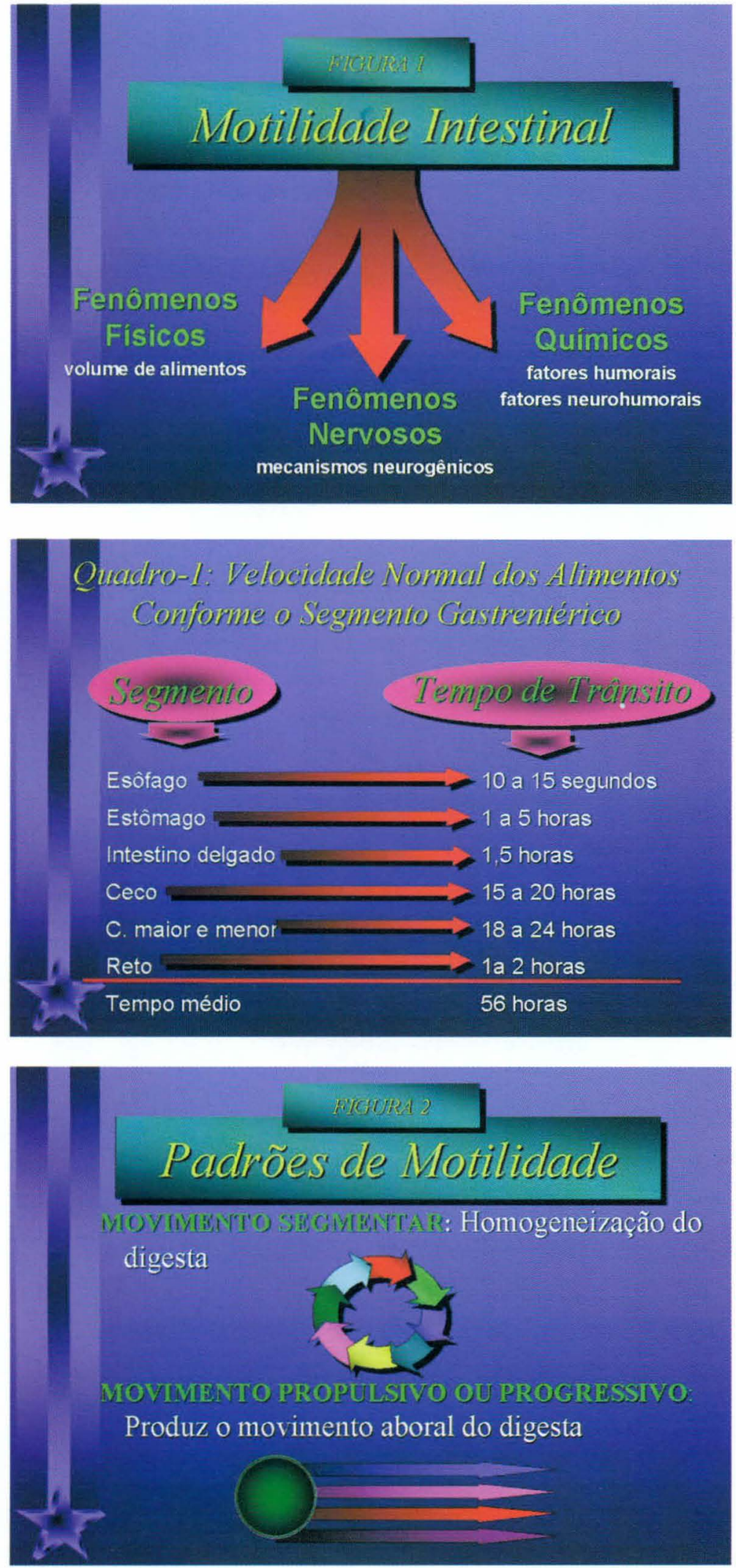

co, como sendo a ausência de qualquer possibilidade imediata de movimento do digesta, seja ele um movimento segmentar ou mesmo progressivo.
Para que se possa estudar e compreender alguns dos processos obstrutivos do aparelho digestório dos cavalos, há que se ter em mente os principais fenômenos fisiológicos que modulam e se constituem nas Bases Fisiológicas da Digestão e Progressão dos Alimentos.

Segundo WOLTER ${ }^{18}$, “ A fisiologia digestiva do cavalo se caracteriza por intensa mastigação, grande rapidez do trânsito gástrico, uma digestão enzimática breve, porém intensa no intestino delgado, e uma prolongada ação microbiana a nível dos grandes reservatórios do intestino grosso."

O trato gastrentérico dos eqüinos apresenta características anatômicas e fisiológicas peculiares em relação ao de outras espécies domésticas, sendo classificado como herbívoro monogástrico, apresentando, entretanto, fenômenos de digestão no ceco e cólon maior, semelhantes aos poligástricos.

Para que os alimentos ingeridos pelos cavalos possam servir de substrato às necessidades de mantença do organismo, e de suporte ao metabolismo no trabalho, na gestação e em outras atividades do animal, é necessária uma adequada e sincrônica interação entre os fenômenos de digestão propriamente ditos, assim como a resultante motora que possa transportar os alimentos de um segmento digestivo ao outro, para que estes sejam devidamente umectados, desdobrados em componentes nutritivos mais simples, absorvidos e os seus resíduos eliminados como matéria fecal.

A motilidade gastroentérica normal é dependente principalmente de fenômenos físicos, químicos e nervosos (Figura 1). O volume e a qualidade dos alimentos ingeridos, a presença de fatores humorais e neurohumorais, aliados à ação de mecanismos neurogênicos, são fundamentais para desencadearem o trabalho da musculatura da parede do trato gastrentérico, e, consequentemente, ocorrer movimento com transporte do alimento para cada segmento, dentro de suas características anátomo-fisiológicas (Quadro 1).

A motilidade do trato gastroentérico é classificada em dois tipos padrão (Figura 2):

1 - Movimento Segmentar

2 - Movimento Propulsivo ou Progressivo 
O Movimento Segmentar é o que proporciona a homogeneização do digesta, misturando os alimentos e otimizando a função de digestão dos diversos sucos necessários ao desdobramento dos nutrientes.

O Movimento Propulsivo ou Progressivo se encarrega de transportar os alimentos aos diversos segmentos aborais, permitindo a ação progressiva de desdobramento alimentar.

\section{Estômago}

A motilidade do estômago ocorre por contração de sua musculatura para possibilitar a mistura do ácido e de enzimas para o início da digestão de gorduras e proteínas. A contração do estômago movimenta o ingesta por fases de digestão, e depende da qualidade do alimento (concentrado / volumoso) em relação a sua digestibilidade e apresentação física (tamanho da partícula).

Os fenômenos de digestão e de progressão dos alimentos do estômago dos eqüinos são particularmente muito semelhantes ao que ocorre no estômago de outras espécies de monogástricos, sendo dependente da ação de enzimas alimentares, microorganismos e do suco gástrico. Entretanto, é importante que se ressalte que a capacidade volumétrica do estômago do cavalo, em relação à capacidade total de seu aparelho digestório, deve ser levada em conta quando se estudam os vários fenômenos da digestão química, do seu enchimento, do seu esvaziamento e a estimulação, em cadeia, dos segmentos digestivos subseqüentes (reflexo gastrocólico).

Neste sentido, a digestão gástrica total acontece em 3 fases distintas:

1 - Fase Cefálica: mediada pelo nervo vago em razão do olfato e paladar, desencadeando estímulo reflexo de liberação de saliva e sucos digestivos.

2 - Fase Gástrica propriamente dita, dividida em duas:

a - Mecânica: caracterizada pela distensão do estômago provocando como resposta a contração do órgão e o aumento da liberação de gastrina.

b - Química: desencadeada pela liberação da gastrina pelas células do antro devido à presença de catabólitos da digestão de proteínas.

Ambos os mecanismos desta fase gástrica são ainda mediados por reflexos locais entérico-nervosos.
3 - Fase Entérica: iniciada com a passagem do alimento ao intestino delgado que desencadeia a fase intestinal da secreção gástrica. Esta secreção é mediada pela secreção de gastrina de células situadas no duodeno.

A Fase Gástrica da digestão pode sofrer alterações decorrentes principalmente das seguintes situações que predispõem à indigestão:

1 - Produção insuficiente de suco gástrico (trabalho físico ou psíquico imediatamente antes e após a ingestão de alimentos).

2 - Ingestão rápida de alimentos.

3 - Ingestão excessiva de alimentos.

4 - Formação de massa pegajosa em presença de excesso de carboidratos (triturado) no alimento.

Quanto à produção de ácido clorídrico proveniente de células da região fúndica, é importante considerar a participação de vários fatores interdependentes e integrados em seu controle, fundamentais para os processos de digestão dos alimentos e da osmolaridade do meio gástrico como:

\section{1 - Ativação do pepsinogênio \\ 2 - Secreção de bicarbonato \\ 3 - Secreção do muco \\ 4 - Fermentação microbiana no estômago \\ 5 - Motilidade gástrica \\ 6 - Esvaziamento gástrico}

O esvaziamento gástrico se processa conforme os tipos de alimentos ingeridos e o grau de digestão (qualidade e tamanho das partículas). O retardo no esvaziamento gástrico é controlado por mecanismos neurais e influência hormonal do duodeno. O aumento da osmolaridade do duodeno reduz o esvaziamento gástrico. A elevação das secreções gástricas pelos mecanismos duodenais, fase intestinal da digestão gástrica, também possibilita o retardo no esvaziamento do estômago. Cadeias de ácidos graxos de 12 a 18 átomos de carbono são capazes de reduzir a velocidade de esvaziamento, sendo que estes ácidos são mediados pela liberação de colecistoquinina. O esvaziamento gástrico também pode ser estimulado pela distensão da parede e mediado pelo nervo vago.

\section{Intestino Delgado}

A digestão dos alimentos a nível do intestino delgado consiste no processamento químico da mistura dos 
THOMASSIAN, ARMEN. Restabelecimento do trânsito intestinal em eqüinos - Parte I: fisiologia e fisiopatologia. Revista de Educação Continuada do CRMV-SP / Continuous Education Journal CRMV-SP. São Paulo, volume 2, fascículo 1, p. 9 - 16, 1999.

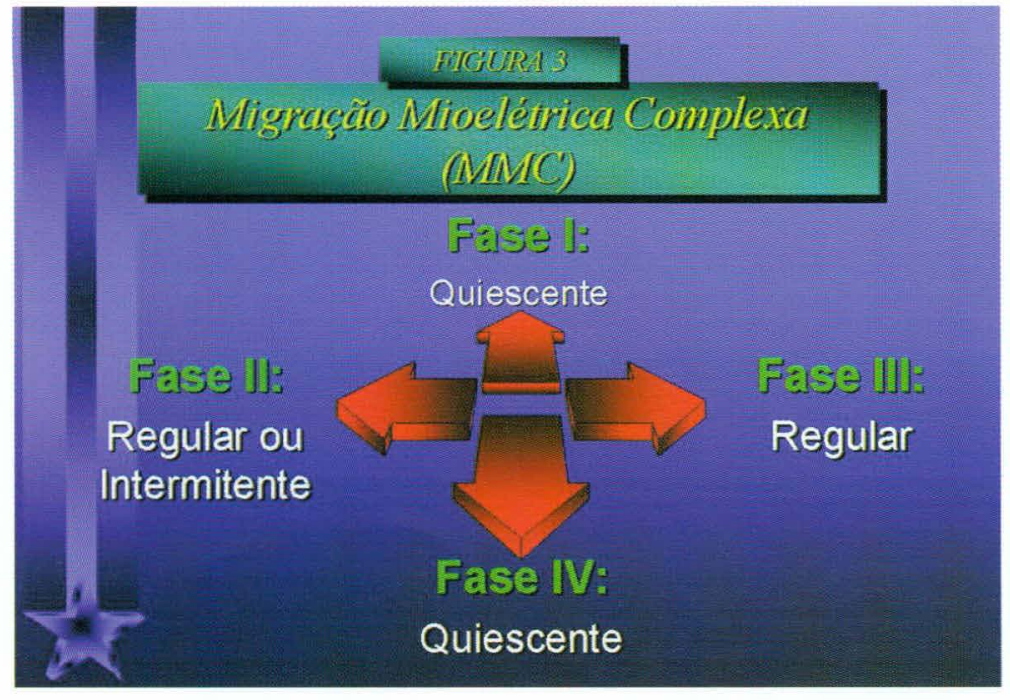

alimentos com saliva, suco gástrico e com as secreções do pâncreas, fígado e do próprio intestino delgado. A passagem dos alimentos através deste segmento entérico basicamente compreende a digestão e absorção dos carboidratos, digestão de proteínas, digestão de gorduras, regulação do $\mathrm{pH}$ do digesta, manutenção do equilíbrio hidroeletrolítico e formação e fluxo da linfa.

A motilidade do intestino delgado, consequentemente do digesta, se faz principalmente por controle neural e é regulada por marca-passos que desencadeiam a atividade mioelétrica segmentar e propulsiva denominada de Migração Mioelétrica Complexa (MMC), sendo este fenômeno dependente de íons cálcio.

As diversas características da motilidade do intestino delgado são moduladas neurologicamente pelo que se denomina Controle Neural dos Movimentos.

O Controle Neural dos Movimentos do intestino delgado se processa segundo: distensão de alças, estimulação de receptores beta 1 e 2 adrenérgicos e estimulação de receptores alfa 1, beta 1 e 2 localizados no íleo.

Obs: tanto o Controle Neural Intrínseco como o Controle Neural Extrínseco estão conectados ao S.N.C. através do nervo vago e do plexo esplâncnico.

A atividade de Migração Mioelétrica Complexa (MMC), principal responsável pela motilidade do intestino delgado, se caracteriza por 3 fases dinâmicas propriamente ditas (Figura 3):

\section{1- Fase I: Quiescente}

2- Fase II: Regular ou intermitente

\section{3- Fase III: Regular}

4- Fase IV: Quiescente

A Migração Mioelétrica Complexa (MMC) é influenciada pelo grau de repleção da alça, grau de digestão dos alimentos e se o animal está ou não sendo submetido a jejum ou alimentando-se regularmente. Neste sentido, conforme a característica da alimentação e da fase da atividade mioelétrica, o clínico irá detectar mudanças nos padrões de auscultação dos focos intestinais.

O intestino delgado realiza três tipos de movimentos, a saber (Figura 4):

1 - Peristáltico progressivo: progressão rápida

2 - Segmentar: progressão lenta e rítmica

3 - Pendular: caracterizado por contração simples, ao acaso, após 3 a 4 ondas longitudinais lentas.
1 - Atividade Intrínseca: representada pelos plexos murais de Auerbach's e Meissner's, que são os responsáveis pelo desencadeamento da transmissão neuro-muscular que proporciona a resposta motora intrínseca.

2 - Atividade Extrínseca: representada pelo Sistema Nervoso Autônomo que atua estimulando ou inibindo os movimentos conforme:

a - estimulação da motilidade através do sistema parassimpático, representado por vias sensitivas e motoras do nervo vago e do plexo sacral.

b - redução da motilidade intestinal através do sistema simpático em condições de

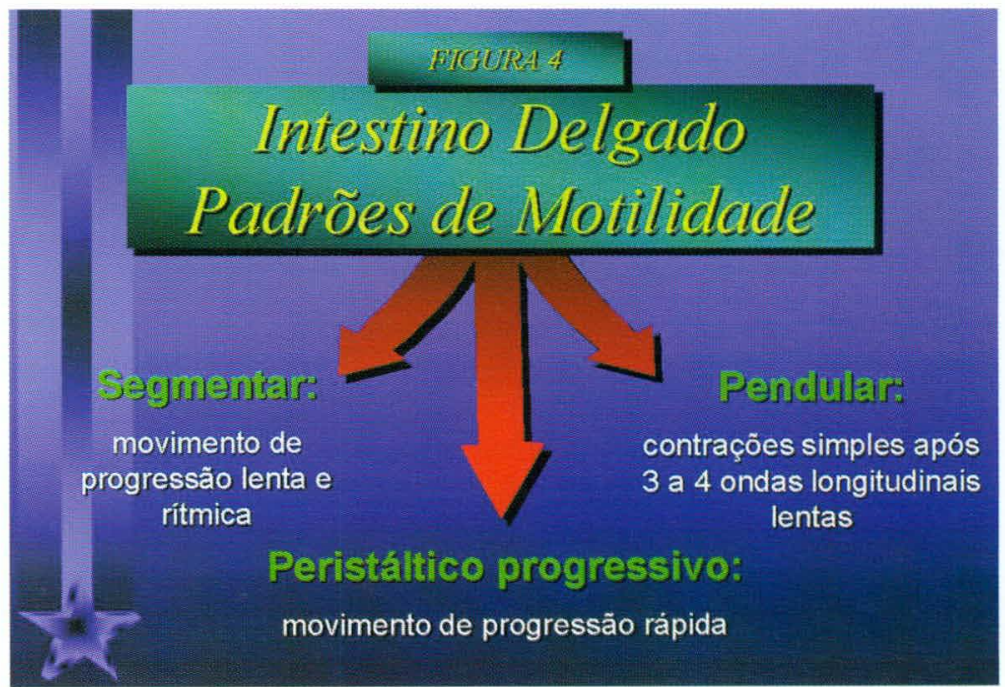


A ação conjunta dos diversos movimentos decorrentes do enchimento e esvaziamento do intestino delgado promove a progressão da massa do digesta em direção às porções terminais do íleo e em direção ao ceco, estimulando o reflexo enterocólico.

\section{Ceco}

O ceco é a grande cuba de fermentação dos alimentos, correspondendo ao rúmen dos bovinos como principal degradador de fibras.

As funções do ceco são as de digerir carboidratos, gorduras e fibras, notadamente através da flora composta de protozoários e bactérias. O ceco, através de sua flora, supre o organismo das necessidades de proteínas de fontes não nitrogenadas, sob a forma de aminoácidos específicos, e de vitaminas como a tiamina, riboflavina, ácido nicotínico, piridoxina, ácido fólico entre outras. As bactérias se ligam por simbiose às fibras e degradam-nas com enzimas de sua parede, e os protozoários digerem os restos das fibras, controlando assim a população bacteriana.

Como regulador do equilíbrio hidroeletrolítico, o ceco possui a capacidade de absorver cerca de $2 / 3$ da água e dos eletrólitos provenientes do intestino delgado.

Após forte compressão do digesta no íleo, e sob estímulo da papila ileal, o alimento proveniente do intestino delgado passa ao ceco através da abertura da válvula íleo-cecal e o fechamento da válvula ceco-cólica. É interessante se observar que a papila ileal possui a capacidade de realizar movimentos de protrusão, rotação, retração e pendular (oscilatório), objetivando a passagem dos alimentos.

Fundamentalmente o ceco possui movimentos de mistura dos alimentos por fases, proporcionando condições para a degradação das fibras e a síntese de proteínas e vitaminas. A motilidade e o movimento de esvaziamento do ceco se faz no sentido do ápice para o corpo do ceco (anti-peristáltico), que com o fechamento da válvula íleo-cecal e a abertura da ceco-cólica transporta o digesta em direção ao cólon ventral direito.

As alterações nos movimentos do ceco ocorrem em razão de modificações fisiológicas devido principalmente à qualidade dos alimentos - fibras e digestibilidade - e à quantidade de amônia e de ácidos graxos voláteis produzidos no desdobramento dos carboidratos. Maiores quantidades de ácido acético, butírico e propiônico são produzidas com o aumento da oferta de carboidratos, podendo, além de outras interações indesejáveis, interferir nos padrões de motilidade do ceco, devido à presença de receptores químicos.

\section{Colón maior - cólon menor}

A fisiologia digestiva do cólon maior e menor compreende basicamente os mesmos fenômenos que ocorrem na digestão e absorção de alimentos no ceco, sendo que as porções finais do cólon maior atuariam como mecanismos de regulação das secreções e absorção deste segmento intestinal. A população microbiana do cólon maior é semelhante à encontrada no rúmen dos poligástricos.

Com relação aos eletrólitos, a atividade fisiológica do cólon maior através da bomba de sódio e potássio é a de preservar o sódio e proporcionar um gradiente para que se complete o ciclo hidroeletrolítico, mantendo, entretanto, um grau de umectação que possibilite o transporte do digesta em direção ao cólon menor.

A motilidade do cólon maior depende basicamente da qualidade dos alimentos e da qualidade e grau de digestão. Os movimentos do cólon maior podem ser deprimidos pela estimulação de receptores adrenérgicos alfa 1 e 2. Por outro lado, a estimulação de receptores adrenérgicos beta 1 e 2 é capaz de deprimir a motilidade em diversos segmentos do cólon ventral. A estimulação de receptores beta 1 e 2 , e às vezes de receptores alfa 2 , é capaz de deprimir a motilidade do cólon menor. A motilidade do cólon maior ainda sofre regulação proveniente dos reflexos gastrocólico e enterocólico, e notadamente do marca-passo da flexura pélvica.

O movimento do digesta nos diversos segmentos do cólon maior, e consequentemente o fluxo de conteúdo para o cólon menor, é realizado em harmonia, isto é, enquanto não houver progressão do conteúdo do cólon dorsal, não haverá progressão do conteúdo do ventral. Este movimento pode ser considerado como harmônico, e o seu centro de modulação encontra-se no marca-passo da flexura pélvica.

\section{Reto e defecação}

O cólon menor tem por função absorver parte do conteúdo líquido do digesta, dar forma ao bolo fecal e recobri-lo com película de muco para evitar lesões na mucosa e facilitar a progressão e conseqüente defecação.

A evacuação do intestino se realiza devido à estimulação de centros nervosos autônomos, causada pela distensão da parede do cólon menor na região do reto, que desencadeia uma forte contração progressiva da musculatura lisa do reto (reflexo mioentérico) em direção ao esfíncter anal, que se relaxa e permite a expulsão das fezes. Nesta fase da defecação, a prensa abdominal participa ativamente na progressão e eliminação fecal. 
O ato de defecação pode ser estimulado e acelerado por ação do sistema parassimpático (plexo sacral), e inibida por ação do sistema simpático (plexo hipogástrico).

\section{Regiões do trato gastroentérico que atuam na progressão do digesta}

\section{1 - CÁRDIA \\ 2 - PILORO \\ 3 - VÁLVULA ÍLEO-CECAL \\ 4 - VÁlVULA CECO-CÓlica \\ 5 - FLEXURA PÉLVICA \\ 6 - CÓlON TRANSVERSO-JUNÇÃO COM O CÓLON MENOR}

\section{7 - RETO E ÂNUS}

Além do destaque com relação às diversas regiões do trato gastroentérico e dos processos físicos, químicos e neurohumorais, que participam ativamente na progressão do digesta, deve-se ressaltar que são primordiais para o estabelecimento dos padrões de progressão alimentar os seguintes aspectos:

\section{1 - Qualidade do alimento \\ 2 - Grau de repleção das alças \\ 3 - Manejo alimentar (fibras, concentrados e água)}

4 - Grau de digestão dos diversos alimentos conforme o segmento do trato gastrentérico em que se encontrarem.

\section{Obstrução ao trânsito dos alimentos}

Etiopatogenicamente, os intestinos dos eqüinos podem ser obstruídos, considerando-se notadamente que a parada da movimentação do digesta no sentido aboral pode ser classificada como:

\section{1 - Funcional 2 - Mecânica}

\section{1- Obstrução Funcional}

A obstrução funcional ou o denominado íleo adinâmico, é definida como uma forma de obstrução intestinal caracterizada por um padrão de motilidade irregular e inadequado à movimentação do digesta.

Segundo $\mathrm{BECHT}^{2} \mathrm{o}$ íleo adinâmico pode ser classificado em íleo fisiológico e íleo paralítico. O íleo fisioló- gico seria decorrência previsível no pós-operatório imediato de um grande número de cirurgias abdominais, em que alças intestinais tenham sido intensamente manipuladas. Esta forma de íleo apresenta como característica o retorno espontâneo à motilidade normal após alguns minutos ou horas, sem que se instale no paciente qualquer complicação ao pronto restabelecimento das funções digestivas. Por outro lado, o íleo paralítico é caracterizado por uma diminuição mais difusa da peristalse e até mesmo a instalação de atonia que pode abranger todos os segmentos do trato gastrentérico ou apenas determinadas regiões. Este tipo ou intensidade de íleo pode ser decorrente, principalmente, de complicações no pós-operatório de cirurgias gastrentéricas ou mesmo secundário aos processos de obstrução mecânica dos intestinos, promovendo acúmulo de digesta e seqüestro hidroeletrolítico nos segmentos anteriores à obstrução. $\mathrm{O}$ íleo paralítico se refere também a desequilíbrios eletrolíticos graves, traumas intestinais, peritonites, grandes distensões do tubo gastrentérico, toxemia e choque, entre as causas mais freqüentes. A fisiopatologia do íleo propriamente dito é semelhante às manifestações de obstrução intestinal, e suas consequiências quanto ao trânsito e equilíbrio hidroeletrolítico, desencadeiam comprometimento secundário da parede do intestino. Este comprometimento secundário da parede intestinal é devido à distensão por líquido e gás, proliferação bacteriana e também devido à presença de níveis elevados de secreções do estômago, do pâncreas, dos intestinos e do trato biliar.

A distensão da parede gastrentérica conseqüente ao acúmulo de digesta, fermentação bacteriana e seqüestro ou refluxo hidroeletrolítico promove redução do fluxo sangüíneo aos diversos planos da parede, causando hipóxia que estimula a respiração celular anaeróbia, acúmulo de catabólitos e proporciona a inativação motora das fibras musculares. A distensão promove ainda a reversão da função da parede intestinal, reduzindo a absorção e aumentando o fluxo de secreções, permitindo, desta forma, a retroalimentação do ciclo do íleo.

A despeito do tipo de atonia que se instala no trato gastroentérico, o que fica caracterizado na análise do processo é que a fisiopatologia do íleo é semelhante nos diversos tipos de obstrução intestinal em eqüinos, seja o processo de origem extraluminal ou intraluminal, não estrangulante ou estrangulante dos intestinos e de seus troncos vasculares.

\section{2 - Obstrução Mecânica}

Quando são causadas por processos que obstruem o trânsito intestinal do digesta ou decorrente de pato- 
THOMASSIAN, ARMEN. Restabelecimento do trânsito intestinal em eqüinos - Parte I: fisiologia e fisiopatologia. Revista de Educação Continuada do CRMV-SP / Continuous Education Journal CRMV-SP. São Paulo, volume 2, fascículo 1, p. 9 - 16, 1999.

logias sem estrangulamento entérico ou de seus troncos vasculares, como ocorre nos casos de compactações, sablose e enterólitos, ou ainda devido a processos estrangulantes como em torções do pedículo mesentérico do intestino delgado e a torção do cólon maior como exemplos. Etiopatogenicamente, instalam-se em maior ou menor grau de intensidade os mesmos fenômenos decorrentes do íleo paralítico, isto é, hipotonia ou atonia regional ou difusa.

Portanto, ao se analisar etiopatogenicamente o processo de distensão do trato gastroentérico, fica claro que a parada da motilidade intestinal, e consequentemente do trânsito do digesta, desencadeia aumento das secreções da parede e lesão da mucosa nos mais variados graus de gravidade. Neste sentido, torna-se vital que se restabeleça a fisiologia motora intestinal o mais rapidamente possível, para que se mantenha a homeostase do organismo.

A identificação da categoria etiopatogênica do processo que está acometendo o animal é de fundamental importância, vez que é desta identificação que se tornará possível o planejamento da terapêutica que será instituída.

\section{Categorias etiopatogênicas}

1 - Obstruções intraluminais sem estrangulamento vascular: podem ser fisiológicas ou mecânicas; podem atingir o estômago, intestino delgado, ceco, cólon maior, cólon menor e reto.

2 - Obstruções intraluminais com estrangulamento vascular: sempre de origem mecânica comprometendo grandes troncos vasculares em geral, mesentéricos e cólicos. Podem se instalar no intestino delgado, ceco, cólon maior e raramente no cólon menor.

3 - Obstruções vasculares sem estrangulamento: nos casos de obstruções causadas por processos tromboembólicos ou por compressões extravasculares (tumores e abscessos).

4 - Enterites, Úlceras, Colites e Peritonites.

5 - Dor com origem em outros órgãos: fora do trato gastroentérico (útero, rins, fígado, pâncreas, etc.)

6 - Cólicas idiopáticas: nos quadros indistintos sem origem aparente, com manifestações de desconforto abdominal leve e sem grandes depleções do organismo.

7 - Cólicas iatrogênicas: instituídas pela ação do tratador, treinador, proprietário, médico veterinário e outros. Em geral o processo iatrogênico é conseqüência de aplicações de drogas com ação farmacológica sobre o sistema nervoso autônomo (atropina, neostigmina, imidazol, amitraz, etc.) ou devido a manobras de palpação retal desastrosa.

\section{SUMMARY}

This report approaches some aspects of equine physiological gastroenteric transit and pathophysiology details of digestive tract's mechanical and functional obstruction .

Uniterms: Equine, Physiology, Digestive tract, Intestinal transit, Ileus, Colic

\section{BIBLIOGRAFIA DE APOIO}

1. ADAMS, S.B. Recognition and management of ileus. The Veterinary Clinics of North America - Equine Practice, v. $4, \mathrm{n} 1, \mathrm{p} .91-103,1988$.

2. BECHT, J.L.; RICHARDSON, D.W. Ileus in the horse: clinical significance and management. In: ANNUAL CONVENTION AMERICAN ASSOCIATION EQUINE PRACTITIONERS, 27. AAEP, 1981. Procedings. p.291-7.

3. DABAREINER, R.; WHITE, N.A. Nasogastric intubation in a horse with ileus: the benefits and complications. Veterinary Medicine, v.87, n.9, september, p.927-33, 1992.
4. De GEEST, J. et al. A clinical study of cisapride in horses after colic surgery. Equine Veterinary Education, v.3, n.3, p.138$142,1991$.

5. DOWLING, P.M. Prokinetic drugs: metoclopramide and cisapride. Canadian Veterinary Journal, v.36, February, p.115-116, 1995.

6. EADES, S.C.; MOORE, J.N. Blockade of endotoxin-induced cecal hypoperfusion and ileus with an a 2 antagonist in horses. American Journal of Veterinary Research, v.54, n.4, April, p.586-90, 1993. 
THOMASSIAN, ARMEN. Restabelecimento do trânsito intestinal em eqüinos - Parte I: fisiologia e fisiopatologia. Revista de Educação Continuada do CRMV-SP / Continuous Education Journal CRMV-SP. São Paulo, volume 2, fascículo 1, p. 9 - 16, 1999.

7. GERRING, E.L. et al. A multicentre trial of cisapride in the prophylaxis of equine post operative ileus. Equine Veterinary Education, v.3, n.3, p.143-5, 1991.

8. GERRING, E.L. Factors affecting gut motility. Equine Veterinary Education, v.3, n.3, p.146-8, 1991.

9. GERRING, E.L. Management of intestinal ileus in horses. The Compendium on Continuing Education, v.14, n.8, August, p.1002-3; 1113, 1992.

10.GOREY, T.F. The recovery of intestine after ischaemic injury. British Journal of Surgery, v.67, p.699-702, 1980.

11.KING, J.N.; GERRING, E.L. Disruption of equine bowel motility by endotoxin - evidence of a role for prostaglandins and paf. British Journal of Pharmacology, v.97, Suppl., p. $369 \mathrm{P}$.

12.MESCHTER, C.L. et al. Histologic findings in the gastrointestinal tract of horses with colic. American Journal of Veterinary Research, v.47, n.3, p.598-606, 1986.
13.MITCHELL, A.; COLLIN, J. Vasopressin effects on small intestine: a possible factor in paralytic ileus? British Journal of Surgery, v.72, June, p.462-5, 1985.

14.PARKS, A.H. et al. Effects of distention and neostigmine on jejunal vascular resistance, oxygen uptake, and intraluminal pressure changes in ponies. American Journal of Veterinary Research, v.50, n.1, p.54-8, 1989.

15. RENNIE, J.A. et al. Neural and humoral factors in postoperative ileus. British Journal of Surgery, v.67, p.694-8, 1980.

16. WHITE II, N.A. Modulation of intestinal motility. In: CICLO INTERNACIONAL DE CÓLICA, II. Jaboticabal, SP, 1995. Anais. p. 26-27.

17. WHITE II, N.A. The equine acute abdomen: medical management of colic. Philadelphia: Lea\&Febiger, 1990. p. 17888: treatment to intestinal motility.

18. WOLTER, R. Alimentacion del caballo. Zaragoza: Acribia, 1975. 172p.

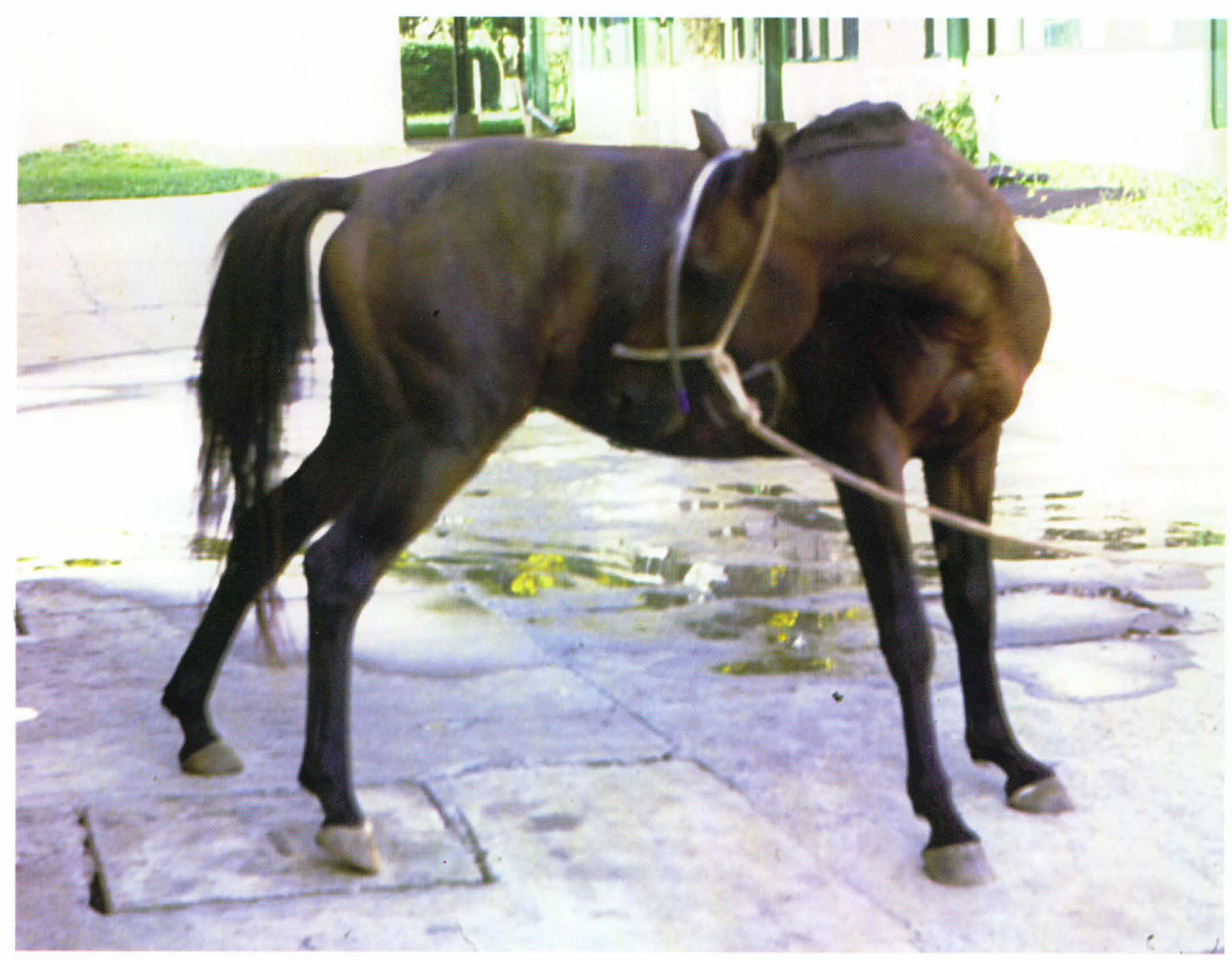

